\title{
Additions to the lichen flora of Tasmania
}

\author{
G. Kantvilas ${ }^{1}$ and A. Vězda ${ }^{2}$
}

\begin{abstract}
Kantvilas, G. ${ }^{1}$ \& Vězda, A. ${ }^{2}\left({ }^{1}\right.$ Tasmanian Herbarium, G.P.O. Box 252C, Hobart, Tasmania, Australia 7001; ${ }^{2}$ Botanical Institute, Czechoslovak Academy of Sciences, 60200 Brno, Tábor 28a, Czechoslovakia) 1992. Additions to the lichen flora of Tasmania. Telopea 4(4): 661-670. Five new lichens are described. Arthonia tasmanica Kantvilas \& Vězda, A. sagenidii Vězda \& Kantvilas and Arthothelium subspectabile Vězda \& Kantvilas are known only from cool temperate rainforest in Tasmania; Gyalideopsis graminicola Vězda \& Kantvilas is an endemic Tasmanian alpine lichen and the first record of the genus from Tasmania Lecanactis subpremnea Kantvilas \& Vězda is described from the rainforests of Tasmania and Victoria.
\end{abstract}

\section{Arthonia sagenidii $V \check{z} z d a \mathcal{E}$ Kantvilas, sp. nov.}

Mycelium in thallo lichenis (Sagenidium molle Stirton) parasitice vel parasymbiotice vigens, haud visibile. Ascocarpia copiosa, minutissima, lentiformia, $0.1-0.15 \mathrm{~mm}$ lata, circa $30 \mu \mathrm{m}$ alta, dispersa vel aggregata, atrofusca. Stratum hypotheciodeum usque ad $10 \mu \mathrm{m}$ altum, pallide fuscum vel fere incoloratum. Stratum ascigerum circa 25-30 $\mu \mathrm{m}$ altum, plus minusve hyalinum, strato epithecioideo atrofusco, in $\mathrm{KOH}$ decolorato. Paraphysoides ramosae anastomosantesque, circa $0.8 \mu \mathrm{m}$ crassae, apicibus capitatis, nigrofuscis, colore in $\mathrm{KOH}$ griseo viridi. Asci clavati, octospori. Ascosporae oblongo-ellipsoideae, incoloratae, 1-septatae, 6-8.5(-9) $\mu \mathrm{m}$ longae, 2-2.2 $\mu \mathrm{m}$ latae.

Type: Australia: Tasmania: Scotts Peak Road, north of Huon River, on thalli of Sagenidium molle on dry trunk of Nothofagus cunninghamii in rainforest, $560 \mathrm{~m}$, G. Kantvilas 525/88 p.p., 23 November 1988 (holo HO; iso GZU, herb. Vězda). The type material of Arthonia sagenidii has been separated from specimens of Sagenidium molle that were distributed as Lichenes Selecti Exsiccati: 2368.

Thallus not apparent or absent, mycelium entirely within the thallus of the lichen Sagenidium molle as a parasite or parasymbiont. Ascocarps numerous, scattered or crowded, \pm roundish and lens-shaped, minute, $0.1-0.15 \mathrm{~mm}$ wide, c. $30 \mu \mathrm{m}$ high, dark brown. Hypothecial layer to $10 \mu \mathrm{m}$ thick, pale brown to almost colourless. Ascigerous layer, c. 25-30 $\mu \mathrm{m}$ thick, \pm hyaline. Epithecioid layer dark brown, fading in $\mathrm{KOH}$. Paraphysoids branched, anastomosing, c. $0.8 \mu \mathrm{m}$ thick, with capitate, blackish apices, persistently greyish green in $\mathrm{KOH}$. Asci broadly clavate, eight-spored, 20-30 x 8-13 $\mu \mathrm{m}$. Ascospores colourless, oblong-ellipsoid, consistently 1-septate, 6-8.5(-9) x 2-2.2 $\mu \mathrm{m}$, the upper cell somewhat larger. Figure 1 (anatomy).

REMARKs: Arthonia sagenidii is well-characterised by the combination of tiny ascocarps and short, 1-septate ascospores. It occurs exclusively as an apparent parasite or parasymbiont on the thallus of Sagenidium molle, a common and widespread lichen in Tasmanian rainforests. The byssoid thallus of Sagenidium forms extensive colonies to $60 \mathrm{~cm}$ wide in locally dry, sheltered habitats, mostly on the undersides of mature, leaning trees of Nothofagus cunninghamii. The new species is very inconspicuous, being visible only as tiny, clustered blackish specks on the surface of the pale greyish Sagenidium substrate. It is apparently rare: neither extensive field work nor a search of numerous herbarium specimens of Sagenidium revealed more than a 

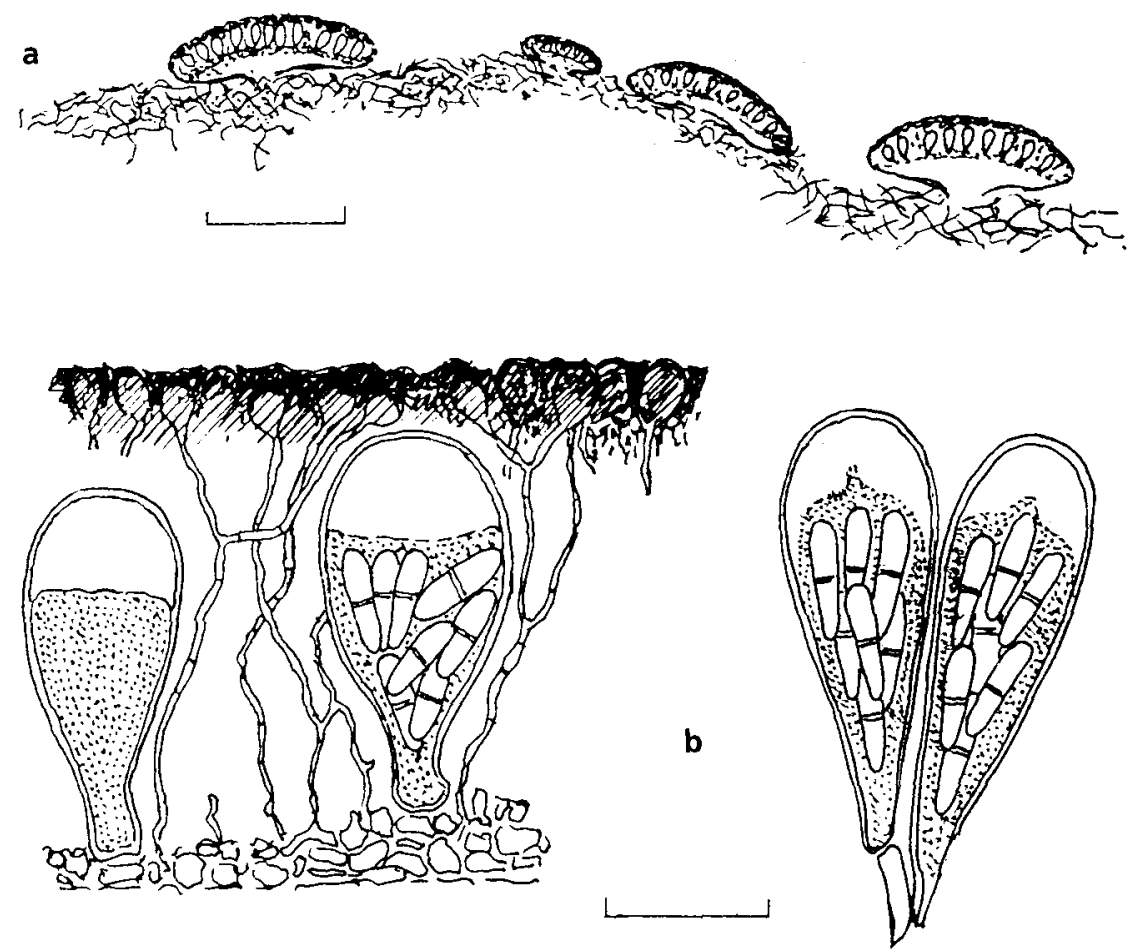

c
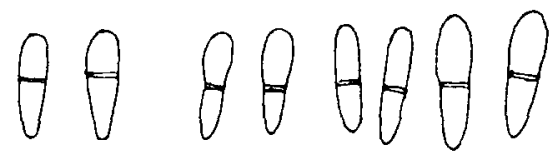

A.V.

Figure 1. Arthonia sagenidii. a, Vertical section of four ascocarps (scale $=0.1 \mathrm{~mm}$ ); $\mathbf{b}$, Asci with paraphysoids; c, Spores. $($ scale $=10 \mu \mathrm{m})$.

few localities. Arthonia sagenidii is frequently associated with Chaenothecopsis sagenidii, which shares the same unique habitat and host.

Specimens eXamined: Australia: Tasmania: Forest track below Mt Victoria, G.C. Bratt 73/1225, 24 November 1973 (HO); Mt Mangana, 420 m, G.C. Bratt 71/1096, 7 August 1971 (HO); Hartz Mts National Park, on Sagenidium molle on Nothofagus cunninghamii in mixed forest, $680 \mathrm{~m}$, M. Wedin 3006, 28 January 1990 (HO, UPS); Scotts Peak Road, $2.5 \mathrm{~km}$ from Gordon River Road, on Sagenidium molle on trunk of Nothofagus cunninghamii in rainforest, $550 \mathrm{~m}, M$. Wedin 3046, 29 January 1990, (HO, UPS).

\section{Arthonia tasmanica Kantvilas \& $V \check{e} z d a$, sp. nov.}

Thallus crustaceus, epi- et hypophloeodes, tenuissimus, sordide cinereus, laevis vel paulo furfuraceus. Ascocarpia copiosa, rotunda, convexa, atra vel atrofusca, epruinosa, $0.2-0.5 \mathrm{~mm}$ lata, $100-130 \mu \mathrm{m}$ crassa. Stratum hypothecioideum hyalinum 
vel pallide fuscum, circa $25-30 \mu \mathrm{m}$ crassum. Stratum ascigerum hyalinum, usque ad circa $70 \mu \mathrm{m}$ crassum, strato epithecioideo rufofusco, olivaceo vel immutato in $\mathrm{KOH}$. Paraphysoides sparsae, ramosae anastomosantesque, circa $1 \mu \mathrm{m}$ crassae. Asci subglobosi, octospori, 40-68 $\mu \mathrm{m}$ longi, 36-56 $\mu \mathrm{m}$ lati. Ascosporae (28-)30-40 x (12-)15-18 $\mu \mathrm{m}$, ellipsoideae vel parum clavatae, rectae vel interdum curvatae, diu hyalinae, in aetate atrofuscae, leviter constrictae praecipue ad septum medium, persaepe triseptatae, rarissime uni vel quadriseptatae, loculis apicalibus quam centralibus valde minoribus, membranis et septis usque ad $2 \mu \mathrm{m}$ crassis.

Type: Australia: Tasmania: Little Fisher River, on Telopea truncata and Atherosperma moschatum in rainforest, $820 \mathrm{~m}$, G. Kantvilas 708/84C, 20 October 1984 (holo HO; iso herb. Vězda).

Thallus crustose, epi- and hypophloeodal, dull dingy grey, very thin, smooth to rather scurfy, forming irregular patches mostly less than $3 \mathrm{~cm}$ wide, occasionally delimited by a thin black line. Ascocarps numerous, roundish, convex, black to blackish brown, 0.2-0.5 mm wide, 100-130 $\mu \mathrm{m}$ thick, becoming somewhat larger, flatter and irregular in outline with age. Hypothecial layer hyaline to pale brown, $c$. $25-30 \mu \mathrm{m}$ thick. Ascigerous layer hyaline, to c. $70 \mu \mathrm{m}$ thick. Epithecioid layer reddish brown to brown, olivaceous or unchanged in $\mathrm{KOH}$. Paraphysoids sparse, branched and anastomosing, c. $1 \mu \mathrm{m}$ thick. Asci subglobose, eight-spored, 40-68 x 36-56 $\mu \mathrm{m}$. Ascospores (28-)30-40 x (12-)15-18 $\mu \mathrm{m}$, ellipsoid to slightly clavate, straight or occasionally curved, hyaline, becoming grey-brown to dark brown with age, contents mostly greyish and granular, especially in $\mathrm{KOH}$, slightly constricted (mostly across the central septum) almost invariably 3 -septate, very rarely 1 or 4 septate with the apical locules markedly smaller than the central ones; walls and septa to $2 \mu \mathrm{m}$ thick. Figure 2 (anatomy).

REMARKs: Arthonia tasmanica is an uncommon and easily overlooked species, known from several widely scattered localities in cool temperate rainforest in Tasmania. It occurs on the smooth bark of various phorophytes (as seen in the case of the type collection) in open or semi-shaded conditions such as on young trees in clearings or on canopy twigs. Associated lichens include Arthothelium ilicinum, Catillaria spp., Parmelia salcrambidiocarpa, Menegazzia weindorferi, Sarrameana tasmanica, Porina leptaleina, Sphaerophorus tener, Rinodina dissa and Thelotrema lepadinum.

The new species is characterised by its rather large, three-septate spores. Although most specimens possessed abundant ascocarps, many sections examined revealed only empty asci or asci with very old, collapsed or heavily brown-pigmented spores with thick walls and septa. The $\mathrm{KOH}+$ olivaceous green reaction of the epithecium, a common feature of many taxa of Arthoniaceae, is variable and intermittent in this species and appears to be of only limited taxonomic value. In gross morphology, Arthonia tasmanica is rather similar to Arthothelium ilicinum, a relatively common species in Tasmanian rainforests with which it frequently co-occurs; $A$. ilicinum has spores of similar overall size but with up to 8 transverse septa and with a significantly enlarged terminal cell.

Specimens examined: Australia: Tasmania: Balts Spur, Tasman Peninsula, on canopy twigs of Nothofagus cunninghamii in rainforest, $420 \mathrm{~m}$, G. Kantvilas 162/83, July 1983 (HO); Adamsons Falls track, on dead Anodopetalum biglandulosum in rainforest, G. Kantvilas 976/81, 26 September 1981 (HO); Mt Victoria track, on Pittosporum bicolor in rainforest, $950 \mathrm{~m}, \mathrm{G}$. Kantvilas 1190/81, 8 December 1981 (HO); Weindorfers Forest, on Nothofagus cunninghamii in rainforest, $920 \mathrm{~m}$, G. Kantvilas 614/88, 6 March 1988 (HO); Anthony Road, on twigs of Atherosperma moschatum in rainforest, 580 m, G. Kantvilas 214/91, 13 May 1991 (HO); Eastern Arthur Range, c. 1 km south of East Portal, on Nothofagus cunninghamii in rainforest, 780 m, G. Kantvilas 125/91, 25 March 1991, (HO); Rebecca Road, south of Arthur River, on fallen branch of Nothofagus cunninghamii, J. Glennie 191, 24 February 1991 (HO). 
a
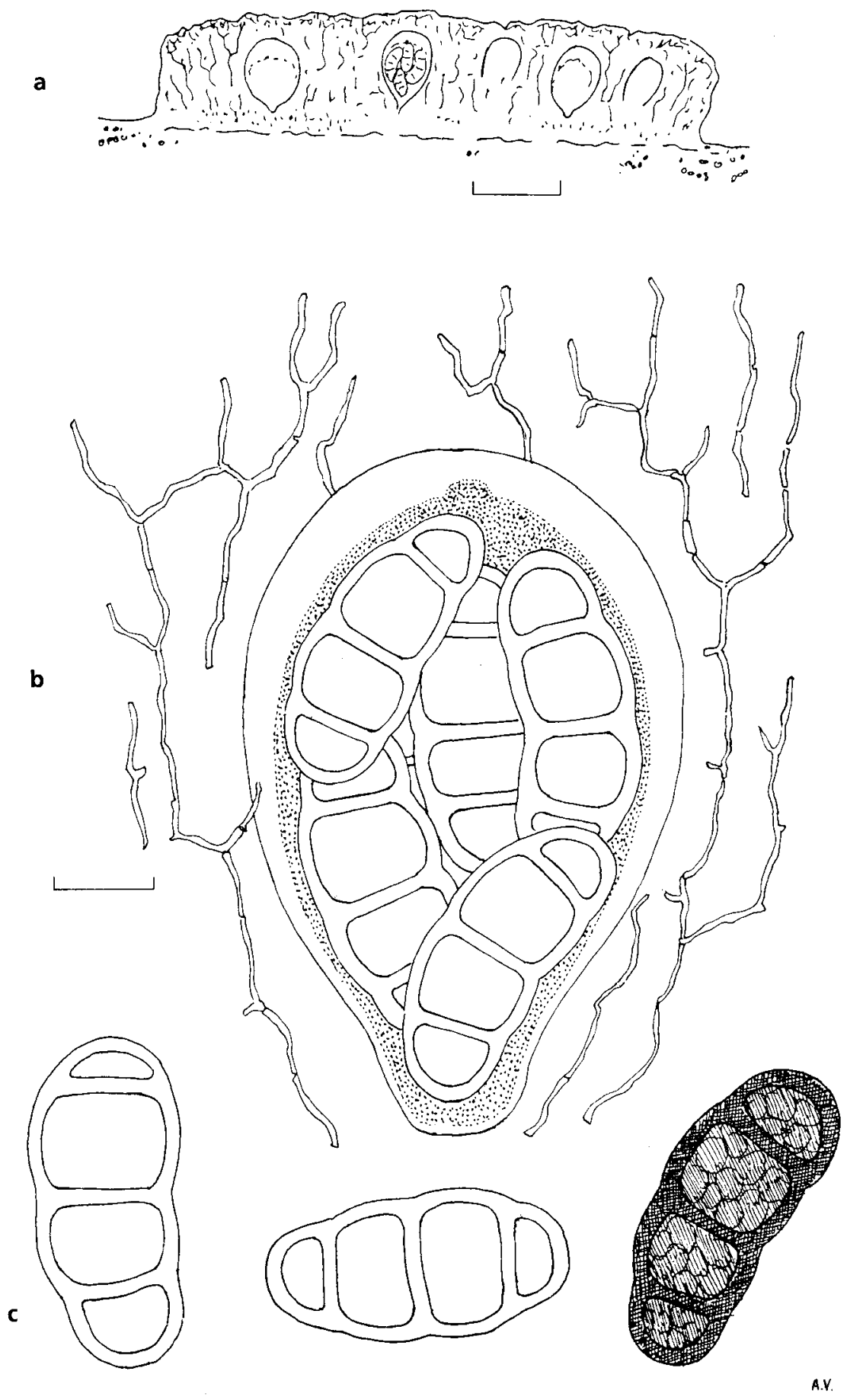

Figure 2. Arthonia tasmanica. $\mathbf{a}$, Vertical section of ascocarp (scale $=0.1 \mathrm{~mm}$ ); $\mathbf{b}$, Ascus with paraphysoids; c, Spores $($ scale $=10 \mu \mathrm{m})$. 


\section{Arthothelium subspectabile $V \check{e} z d a \mathcal{E}$ Kantvilas, sp. nov.}

Thallus crustaceus, epiphloeodes, pro parte etiam hypophloeodes, cinereo-albidus vel sordide olivaceo-cinereus, laevigatus. Alga ad Trentepohliam pertinens. Ascocarpia plus minusve orbicularia, semi-immersa, basin versus constricta, convexa, 0.25-0.4 $(-0.6) \mathrm{mm}$ lata, $0.2-0.25 \mathrm{~mm}$ alta, nigra, opaca, juniora albopruinosa (pruina grosse granulosa), in aetate nuda. Stratum ascigerum $180-200 \mu \mathrm{m}$ crassum, incoloratum vel dilute rufofuscum, superne atrofuscum et granulis copiosis inspersum. Paraphysoides ramosae anastomosantesque, circa 1-1.2 $\mu \mathrm{m}$ crassae. Asci subglobosi, $60-70 \mu \mathrm{m}$ longi, 45-55 $\mu \mathrm{m}$ lati, (2-6-)8-spori. Ascosporae ellipsoideae vel fere ovoideae, muriformes, primum hyalinae, demum atrofuscae, (28-)30-35(-44) $\mu \mathrm{m}$ longae, (14-)15-20 (-24) $\mu \mathrm{m}$ latae.

Type: Australia: Tasmania: $3 \mathrm{~km}$ south-east of Mt Agnew, on dry trunk of mature Nothofagus cunninghamii in rainforest, 190 m, G. Kantvilas 135/89, 6 April 1989 (holo $\mathrm{HO}$; iso herb. Vězda).

Thallus crustose, epiphloeodal and in part hypophloeodal, greyish white to dingy olive-grey, smooth. Photobiont Trentepohlia. Ascocarps \pm rounded, semi-immersed, constricted at the base, convex, $0.25-0.4(-0.6) \mathrm{mm}$ wide, $0.2-0.25 \mathrm{~mm}$ thick, black, opaque, very coarsely granular whitish pruinose when young, soon becoming epruinose. Hypothecial layer poorly developed, \pm pale red-brown to colourless. Ascigerous layer $180-200 \mu \mathrm{m}$ thick, colourless to pale reddish brown, I+ red, in the upper part dark brown, $\mathrm{K}+$ olive-grey and densely inspersed with numerous \pm angular granules; granules mostly to $8 \mathrm{~mm}$ wide, dissolving in K. Paraphysoids branched and anastomosing, 1-1.2 $\mu \mathrm{m}$ thick. Asci subglobose, 60-70 $\mu \mathrm{m}$ long, $45-55 \mu \mathrm{m}$ wide, (2-6-)8-spored. Ascospores ellipsoid to almost ovoid, densely muriform with c. 7-11 transverse and 2-5 longitudinal septa, hyaline at first, becoming dark brown, (28-)30-35 (-44) x (14-)15-20 (-24) $\mu \mathrm{m}$. Figure 3 (anatomy).

ReMARKs: Arthothelium subspectabile is closely related to the western European species, A. spectabile Flotow ex Massal. (see Tehler 1990 for a full description), but differs by its densely granular-white-pruinose young apothecia, by the numerous granules inspersed in the upper part of the hymenium, and by the grey to dark brown mature ascospores. The I+ persistent blue reaction of thalline and subapothecial hyphae, regarded as diagnostic for $A$. spectabile by Coppins \& James (1979) was also not observed in the new species. The two species may also differ chemically: Huneck \& Follmann (1969) report three unidentified substances in $A$. spectabile but no chemical constituents at all were detected by t.l.c. in the new species.

In Tasmania, there are no species easily confused with $A$. subspectabile which is wellcharacterised by its relatively small, convex, pruinose apothecia and densely muriform, \pm ovate spores. Its micro-habitat (see below) is also not shared by any other known species of Arthothelium, although it could well co-occur with several species of the genus Arthonia, particularly A. apteropteridis.

Arthothelium subspectabile is a rare, easily overlooked species, known from only three localities in cool temperate rainforest in western Tasmania. It occurs on the dry, sheltered and deeply shaded trunks of old mature trees (Nothofagus cunninghamii and Lagarostrobos franklinii) and grows on rough, fissured bark or on decorticated wood. It is found in the microhabitats typically colonised by the Lecanactis abietina Sagenidium molle community (Kantvilas 1988: 400) and additional lichens with which it can be associated include Lepraria spp., Bactrospora dryina, Chaenotheca brunneola and species of Chaenothecopsis.

Specimens examined: Australia: Tasmania: approximately $3 \mathrm{~km}$ south of Teepookana, on Lagarostrobos franklinii in rainforest, $220 \mathrm{~m}, \mathrm{G}$. Kantvilas 663/90, 7 November 1990 (HO, herb. Vězda); Badger Creek, c. $2.5 \mathrm{~km}$ south of Greystone Bluff, on trunk of mature Lagarostrobos franklinii in rainforest, $280 \mathrm{~m}, \mathrm{G}$. Kantvilas 78/89, 17 February 1989 (HO). 

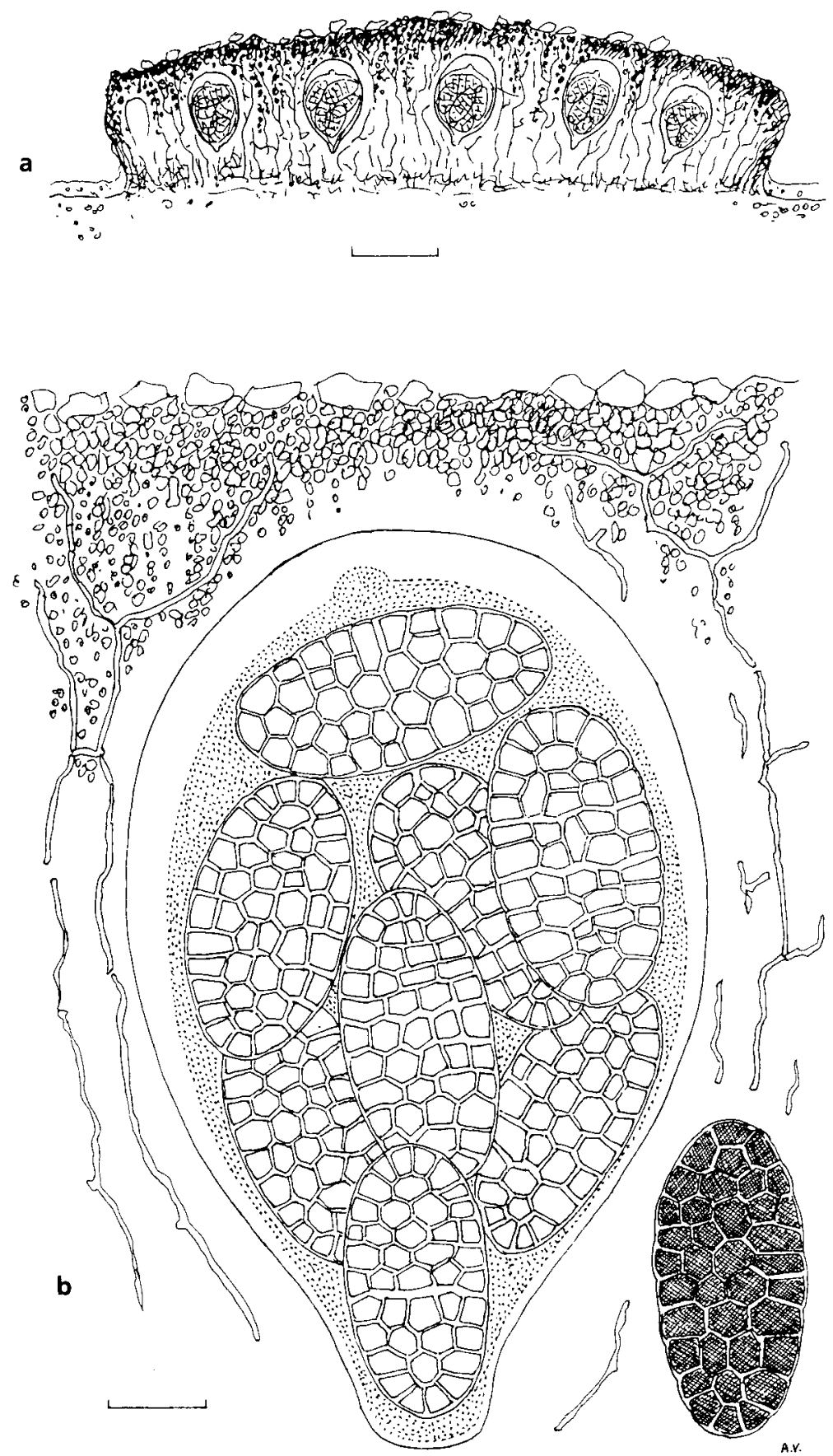

Figure 3. Arthothelium subspectabile. $\mathbf{a}$, Vertical section of ascocarp (scale $=1 \mathrm{~mm}$ ). b, Ascus with paraphysoids and single, aged, free spore (scale $=10 \mu \mathrm{m})$. 


\section{Gyalideopsis graminicola $V \check{z} z d a \&$ Kantvilas, sp. nov.}

Thallus haud visibilis, in textura foliorum graminis emortui vigens. Algae globosae, virides, insulatim agglomeratae. Hyphophori nulli inventi. Apothecia orbicularia, 0.3-0.5 mm lata, circa $0.1 \mathrm{~mm}$ alta, late adnata, basin versus constricta, gyalectoidea, discis concavis vel planis, nigrofuscis, in statu sicco papillis minutissimis nigris munitis, in statu madido fuscis vel rufofuscis subpellucidisque, marginibus persistenter elevatis, integris, nigris, pro parte nitidis. Excipulum 50-60 $\mu \mathrm{m}$ crassum, fuscum vel subhyalinum. Hypothecium circa $40 \mu \mathrm{m}$ altum, hyalinum. Hymenium (100-)120-150 $\mu \mathrm{m}$ altum, incoloratum. Paraphyses sparsae, anastomosantes, tubulis circa $0.8 \mu \mathrm{m}$ crassis. Asci clavati, non-amyloidei, octospori. Ascosporae ellipsoideae, hyalinae, 35$50 \mu \mathrm{m}$ longae, 15-22 $\mu \mathrm{m}$ latae, muriformes, cellulis numerosis, $2-5 \mu \mathrm{m}$ crassis, mox tamen in cellulas liberas decompositae, conidia singula, bacillaria, 2-2.2 $\mu \mathrm{m}$ longa, 0.5 $\mu \mathrm{m}$ lata producentes.

Type: Australia: Tasmania: northern slopes of Mt Jerusalem, on dead Poa tussock in alpine grassland, $1280 \mathrm{~m}, \mathrm{G}$. Kantvilas 114/87, 8 December 1987 (holo HO; iso herb. Vězda).

Thallus not apparent to absent, growing within the tissue of dead grass leaves. Photobiont green, unicellular, cells subglobose and clustered in colonies. Hyphophores not found. A pothecia circular, $0.3-0.5 \mathrm{~mm}$ wide, c. $0.1 \mathrm{~mm}$ tall, broadly adnate, constricted at the base, gyalectoid; disc concave to plane, blackish brown, with minute black papillae when dry, brown to reddish brown and subpellucid when moist, especially in younger apothecia; margins persistently raised, entire, black, partly glossy. Excipulum 50-60 $\mu \mathrm{m}$ thick, brown to subhyaline. Hypothecium c. $40 \mu \mathrm{m}$ thick, hyaline. Hymenium (100-)120-150 $\mu \mathrm{m}$ thick, colourless; paraphyses sparse, anastomosing, $0.8 \mu \mathrm{m}$ thick; asci clavate, non-amyloid, eight-spored. Ascospores ellipsoid, hyaline, 35-50 × 15-22 $\mu \mathrm{m}$, strongly muriform with numerous cells to 2-5 $\mu \mathrm{m}$ wide, with age becoming rather greyish-brown and soon disintegrating into free cells, each producing a single bacillar conidium, $2-2.2 \times 0.5 \mu \mathrm{m}$. Figure $4-5$ (anatomy).

REMARKs: Gyalideopsis is a genus of the Gomphillaceae and currently comprises over 30 species [see James (1975), Galloway (1985) and Vězda \& Poelt (1987) for generic characteristics]. The genus is widely distributed and ranges from cool to tropical climates, with an apparent concentration of taxa in tropical America (Kalb \& Vězda 1988). Three species are known from subtropical rainforest in Australia, including two corticolous taxa (Vězda \& Hafellner 1988) and one as yet undescribed foliicolous species. A further species, also undetermined, is recorded from mosses in New Zealand by Galloway (1985).

The new species is characterised by the absence of a visible thallus, the gyalectoid, plane apothecia and the eight-spored asci with muriform spores. The typically minutely papillose apothecial disc arises from the gradual protrusion of mature asci: the outermost cells of the uppermost spore form a paraplechtenchymatous cortex whilst the remainder of the spore disintegrates into conidia (Figure 5). Such a means of conidial formation from muriform spores is a relatively frequent phenomenon in some foliicolous and corticolous lichens, especially in the families Gomphillaceae and Ectolechiaceae (Santesson 1952: 29).

Gyalideopsis graminicola is a very rare species known only from the type locality, a steep, exposed, badly eroded slope with alpine grassland - heathland mosaic over dolerite, burnt by wildfire approximately 30 years ago. Alpine grassland tends to be an uncommon vegetation formation in Tasmania and usually supports only a depauperate lichen flora of species of Cladonia and Cladia, and Lecanora broccha. The new species was locally common on dead, weather-bleached Poa tussocks and mats of dried leaves, and was not associated with any other lichens. 

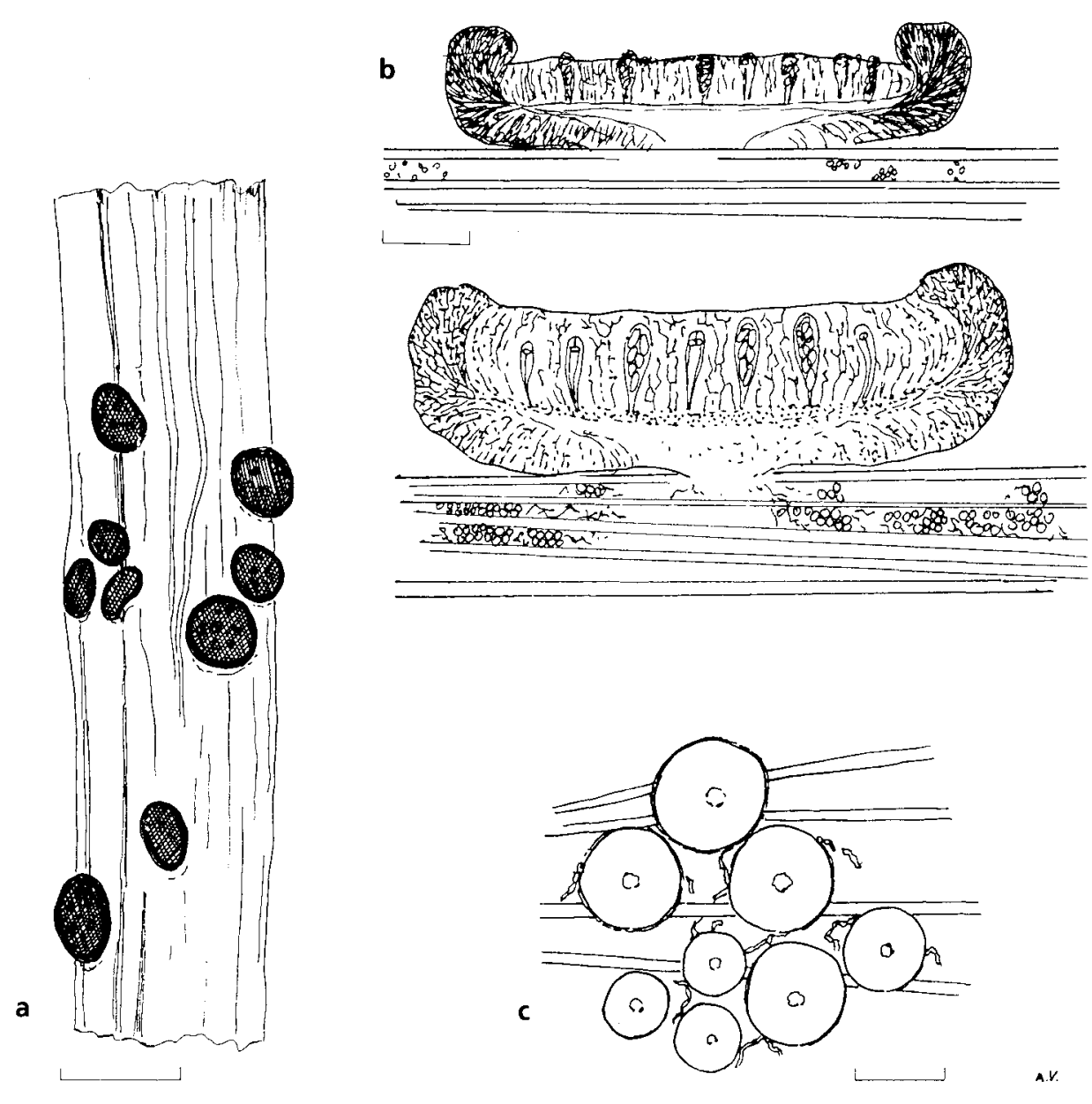

Figure 4. Gyalideopsis graminicola. $\mathbf{a}$, Habit (scale $=1 \mathrm{~mm}$ ). $\mathbf{b}$, Vertical section of apothecium in dry state (above) and in moist state (below) (scale $=0.1 \mathrm{~mm}$ ). c, Algal cells with mycelial hyphae $($ scale $=10 \mu \mathrm{m})$.

\section{Lecanactis subpremnea Kantvilas $\mathcal{E} V \check{z} z d a$, sp. nov.}

Ex affinitate Lecanactidis premneae (Ach.) Arnold a qua differt paraphysibus in apicibus haud nigrofuscis in $\mathrm{KOH}$, sporisque valde majoribus, $30-52 \mu \mathrm{m}$ longis.

Type: Australia: Tasmania: Corinna Road, c. $6 \mathrm{~km}$ west of Waratah, on old trunk of Nothofagus cunninghamii in rainforest, $600 \mathrm{~m}$, G. Kantvilas 71/82, 9 February 1982 (holo $\mathrm{HO}$; iso BM, herb. Vézda, GZU, WELT).

Thallus effuse, rather scurfy, dull olivaceous grey-green, very thin to \pm absent. Apothecia black, matt, lecideine, to $1.7 \mathrm{~mm}$ diameter; margin prominent, persistent, inrolled and lightly greyish pruinose on the inner edge in very young apothecia; disc concave and \pm pruinose only when very young, soon becoming epruinose, plane or 

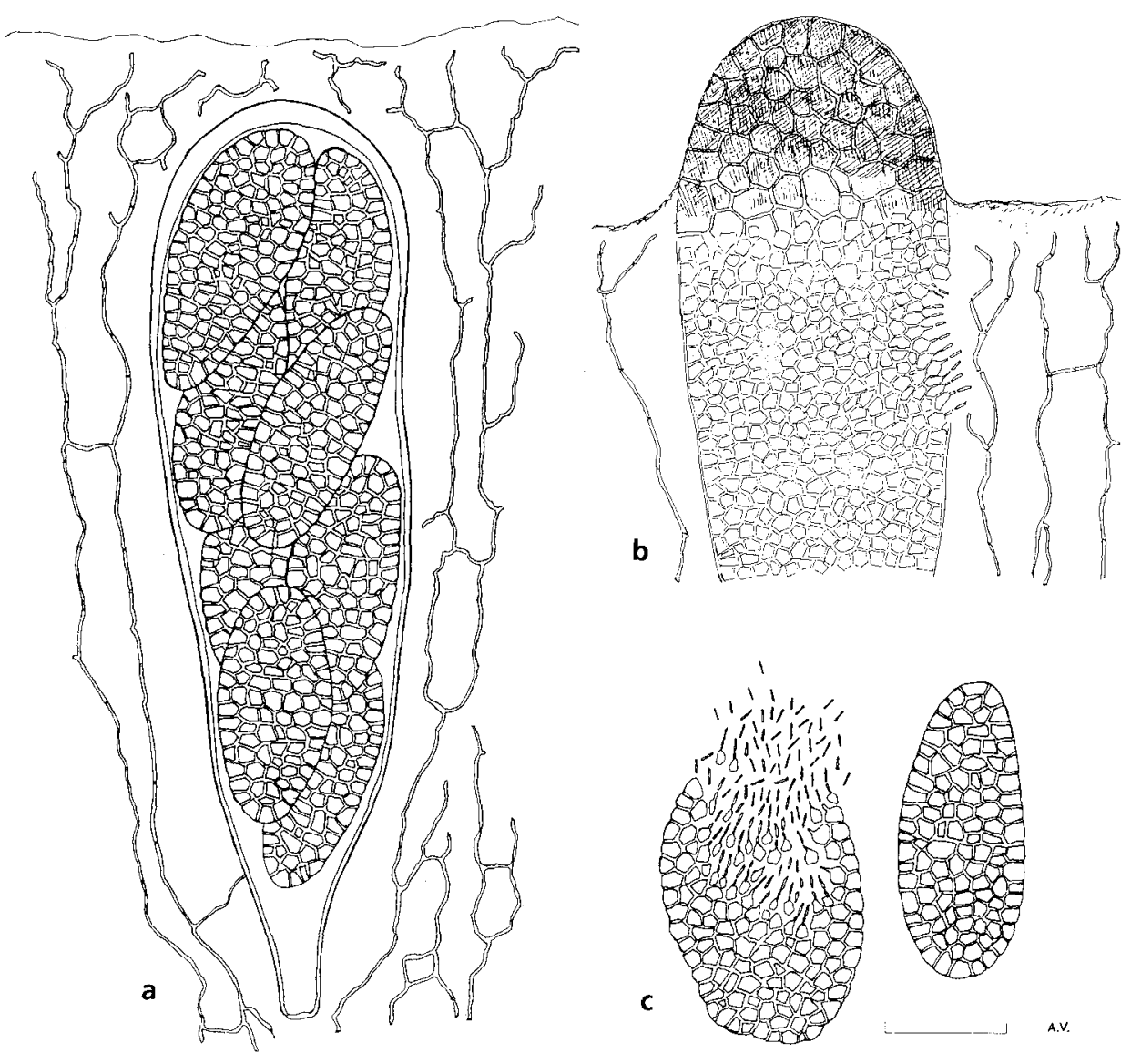

Figure 5 Gyalideopsis graminicola. a, Ascus with paraphyses; $\mathbf{b}$, Old ascus with paraplectenchymatous cortex and decomposed spores, with cells producing conidia; $\mathbf{c}$, Spores, LHS producing conidia. $($ scale $=10 \mu \mathrm{m})$.

undulate, sometimes \pm excavate when very old. Exciple opaque dark brown to brownish black, slightly paler brown at the inner edges, (80-)85-110 $\mu \mathrm{m}$ thick laterally, $\mathrm{K}+$ olivaceous green, mainly at the edges. Epithecium (6-)10-20 $\mu \mathrm{m}$ thick, dark yellow-brown, colourless to very pale yellow brown in $\mathrm{KOH}$. Hymenium colourless, 90-120 (-130) $\mu \mathrm{m}$ thick. Hypothecium colourless, (60-)80-110 $\mu \mathrm{m}$ thick. Paraphyses numerous, flexuous, $1.2-1.5 \mu \mathrm{m}$ thick, simple to sparingly branched towards the apices; apices pigmented yellow-brown, colourless in $\mathrm{KOH}$, usually swollen to c. $2.5 \mu \mathrm{m}$. Asci narrow cylindrical, non-amyloid, eight-spored, (65-)80-100 x (13-)16-18 $\mu \mathrm{m}$. Ascospores fusiform, straight or occasionally curved, with rounded apices, (30-)34-52 x 4-7.5 $\mu \mathrm{m}, 7-9(-10)$ septate, walls to $0.8 \mu \mathrm{m}$ thick.

SPecimens examined: Australia: Tasmania: Near Granville Harbour, on Atherosperma moschatum in rainforest, $140 \mathrm{~m}$, G. Kantvilas s.n., 4 March 1982 (HO); Anthony Road, on dry trunk of Dicksonia antarctica in rainforest, $450 \mathrm{~m}, \mathrm{G}$. Kantvilas 215/91, 10 May 1991 (HO, LSU, herb. Vězda). Victoria: Cement Creek, $37^{\circ} 42^{\prime} \mathrm{S}, 145^{\circ} 44^{\prime} \mathrm{E}$, on Nothofagus cunninghamii in rainforest, G. Kantvilas s.n., 6 October $1983(\mathrm{HO})$. 
REMARKS: Lecanactis subpremnea is closely related to the western European species, L. premnea, from which it differs chiefly by the pigmentation of the paraphyses (these remain apically black in $\mathrm{KOH}$ in $L$. premnea) and the significantly larger spores (17$27 \times 4-7 \mu \mathrm{m}$ in $L$. premnea). The new species is conspicuous but very rare. It is known from cool temperate rainforest in Victoria and western Tasmania where it forms widespreading colonies to c. $20 \mathrm{~cm}$ wide on the shaded, dry trunks of mature trees, as well as on the dry fibrous trunks of tree ferns (Dicksonia antarctica). Lecanactis premnea occupies an analogous niche on old trees in Europe (James et al. 1977).

\section{Acknowledgments}

We thank Dr S.J. Jarman for comments on the manuscript, Mr M. Wedin for the gift of some selected specimens, and the Mapping Branch of the Tasmanian Forestry Commission for reproduction of figures. Financial support to the first author from the National Rainforest Conservation Program and the Office of the National Estate is gratefully acknowledged.

\section{References}

Coppins, B.J. \& James, P.W. (1979) New or interesting British lichens III. Lichenologist 11: 27-45. Galloway, D.J. (1985) Flora of New Zealand Lichens (Government Printer: Wellington).

Huneck, S. \& Follman, G. (1969) Mitteilungen über Flechteninhaltsstoffe. LXIX. Zur Phytochemie und Chemotaxonomie der Arthoniaceae. Österr. Bot. Z. 117: 163-175.

James, P.W. (1975) The genus Gyalideopsis Vězda in Britain. Lichenologist 7: 155-161.

James, P.W., Hawksworth, D.L. \& Rose, F. (1977) Lichen communities in the British Isles: A preliminary conspectus. Pp. 295-413 in M.R.D. Seaward (ed.), Lichen Ecology (Academic Press: London, New York, San Francisco).

Kalb, K. \& Vězda, A. (1988) Neue oder bemerkenswerte Arten der Flechtenfamilie Gomphillaceae in der Neotropis. Bibliotheca Lichenologica 29: 1-80.

Kantvilas, G. (1988) Tasmanian rainforest lichen communities: a preliminary classification. Phytocoenologia 16: 391-428.

Santesson, R. (1952) Foliicolous Lichens I. A revision of the taxonomy of the obligately foliicolous, lichenized fungi. Symb. Bot. Upsal. 12: 1-590.

Tehler, A. (1990) A new approach to the phylogeny of Euascomycetes with a cladistic outline of Arthoniales focussing on Roccellaceae. Can. J. Bot. 68: 2458-2492.

V̌zzda, A. \& Hafellner, J. (1988) Zwei neue Gyalideopsis - Arten aus den Regenwäldern Australiens: G. perlucida und G. rogersii (lichenisierte Ascomycetes, Gomphillaceae). Preslia 60: 239-243.

Vězda, A. \& Poelt, J. (1987) Flechtensystematische Studien XII. Die Familie Gomphillaceae und ihre Gliederung. Folia Geobot. Phytotax. 22: 179-198. 